\title{
CAMTA1 Immunostaining is not Useful in Differentiating Epithelioid Hemangioendothelioma from its Potential Mimickers
}

\section{CAMTA1 İmmünekspresyonu Epitelioid Hemangioendotelyomun Taklitlerinden Ayrımında Kullanışlı Değildir}

\section{Dear Editor,}

The recent report on "CAMTA1 Immunostaining" is very interesting (1). Yusiflı et al. concluded that "epithelioid hemangioendothelioma, its potential morphological mimickers and other benign or malignant vascular tumors showed strong and diffuse CAMTA1 expression, nullifying the potential use of CAMTA1 immunohistochemistry as an adjunct in the differential diagnosis (1)." In fact, the diagnosis of epithelioid hemangioendothelioma is challenging. The use of immunohistochemistry is usually of limited use for the diagnosis. As Lee noted, histopathology alone is not adequate for diagnosis. Lee et al. suggested using "fluorescence in situ hybridization" that could help identify "the presence of CAMTA1 rearrangement" in epithelioid hemangioendothelioma (2). A more complex diagnostic tool, FISH or RT-PCR analysis, can also be useful as a standard tool for the diagnosis of epithelioid hemangioendothelioma (3). The "presence of WWTR1-CAMTA1 fusion" is the diagnostic hallmark from FISH or RT-PCR analysis (3). Errani et al. also noted that it is necessary to use FISH or RT-PCR analysis for the diagnosis since it can help distinguish epithelioid hemangioendothelioma from other malignant epithelioid vascular tumors (4).

\section{REFERENCES}

1. Yusıflı Z, Kösemehmetoğlu K. CAMTA1 immunostaining is not useful in differentiating epithelioid hemangioendothelioma from its potential mimickers. Turk Patoloji Derg. 2014;30:159-65.

2. Lee SE, Park HY, Kim S, Bang H, Min JH, Choi YL. Epithelioid hemangioendothelioma with extensive cystic change and CAMTA1 rearrangement. Pathol Int. 2013;63:502-5.

3. Errani C, Zhang L, Sung YS, Hajdu M, Singer S, Maki RG, Healey $\mathrm{JH}$, Antonescu CR. A novel WWTR1-CAMTA1 gene fusion is a consistent abnormality in epithelioid hemangioendothelioma of different anatomic sites. Genes Chromosomes Cancer. 2011;50:644-53

4. Errani C, Zhang L, Panicek DM, Healey JH, Antonescu CR. Epithelioid hemangioma of bone and soft tissue: A reappraisal of a controversial entity. Clin Orthop Relat Res. 2012;470:1498-506.

\section{Viroj WIWANITKIT}

Visiting Professor, Hainan Medical University, China; Visiting Professor, Faculty of Medicine, University of Nis, Serbia; Adjunct Professor, Joseph Ayobabalola University, Nigeria; Honorary Professor, Dr DY Patil Medical University, Thailand

Wiwanitkit House, Bangkhae 10160, BANGKOK, THAILAND

Email:wviroj@yahoo.com

Phone: +66 892348832 